YEARBOOK

of ANTITRUST

and REGULATORY

STUDIES

www.yars.wz.uw.edu.pl
Peer-reviewed scientific periodical, focusing on legal and economic issues of antitrust and regulation. Creative Commons Attribution-No Derivative Works 3.0 Poland License.

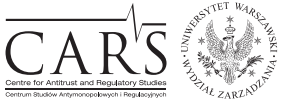

Centre for Antitrust and Regulatory Studies, University of Warsaw, Faculty of Management www.cars.wZ.uw.edu.pl

\title{
Review of the New Polish Model of Abstract Control of Standard Forms of Agreements Concluded with Consumers
}

\author{
by
}

Paulina Korycińska-Rządca*

\section{CONTENTS}

I. Introduction

II. New model of abstract control of standard forms of agreements concluded with consumers

1. Proceedings in cases for the classification of contractual provisions found in standard forms of agreements as abusive clauses

2. Decisions in cases for the classification of contractual provisions found in standard forms of agreements as abusive clauses

3. Limitation period

4. Fines

5. Role of the register of contractual provisions found in standard forms of agreements classified as abusive clauses

III. Conclusions

\section{Abstract}

The Polish Act of 5 August 2015 amending the Act on Competition and Consumer Protection and certain other acts introduced several changes intended to strengthen consumer protection. Its substantial part concerns the abstract control of standard forms of agreements concluded with consumers. The Amendment Act of 2015 has completely changed the previous model of abstract control of standard forms of

* PhD candidate at the Department of Public Economic Law at the University of Białystok, legal counsel in Kancelaria Radców Prawnych Bieluk i Partnerzy; p.korycinska@gmail.com. Article received: 7 November 2016; accepted: 20 November 2016.

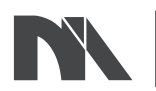

Ministry of Science and Higher Education

Republic of Poland
The creation of the English-language version of these publications is financed in the framework of contract No. 768/P-DUN/2016 by the Ministry of Science and Higher Education committed to activities aimed at the promotion of education. 
agreements concluded with consumers by replacing the court proceedings model with the administrative proceedings model. This article presents an analysis of Polish legal rules on the abstract control of standard forms of agreements concluded with consumers as amended by the Amendment Act of 2015. Its purpose is to verify whether the new Polish model may be deemed as an appropriate and effective means of preventing the continued use of unfair terms, within the meaning of Council Directive 93/13/EEC of 5 April 1993 on unfair terms in consumer contracts. The paper analyses the legal rules on the new model of abstract control of standard forms of agreements concluded with consumers (the administrative proceedings model) and compares the new model with its predecessor (the court proceedings model). The paper does not cover the remaining changes introduced into the Polish Competition Act of 2007 by the Amendment Act of 2015, which are not connected to abstract control of standard forms of agreements concluded with consumers.

\section{Résumé}

La loi polonaise du 5 août 2015 modifiant la loi sur la concurrence et la protection des consommateurs et certains d'autres actes a introduit plusieurs modifications qui ont eu pour leur objectif de renforcer la protection des consommateurs. Sa partie substantielle concerne le contrôle abstrait des formulaires types des contrats conclus avec des consommateurs. La loi de 2015 a complètement modifié le modèle antérieur de contrôle abstrait des formulaires types des contrats conclus avec des consommateurs en remplaçant le modèle judiciaire par le modèle administratif. Cet article présente une analyse des règles juridiques polonaises relatives au contrôle abstrait des formulaires types des contrats conclus avec des consommateurs introduits par la loi de 2015. Son objectif est de vérifier si le nouveau modèle polonais peut être considéré comme un moyen approprié et efficace pour empêcher l'application des clauses abusives dans les contrats, au sens de la directive du Conseil n 93/13/CEE du 5 avril 1993 relative aux clauses abusives dans les contrats conclus avec les consommateurs.

Larticle analyse des règles juridiques du nouveau modèle de contrôle abstrait des formulaires types des contrats conclus avec des consommateurs (le modèle de la procédure administrative) et compare le nouveau modèle avec son prédécesseur (le modèle de la procédure judiciaire). Larticle ne se réfère pas aux autres modifications introduites par l'amendement de 2015 dans la loi polonaise sur la concurrence de 2007, n'étant pas liées au contrôle abstrait des formulaires types des contrats conclus avec des consommateurs.

Key words: consumer protection; abusive clauses; register of abusive clauses; standard forms of agreements; proceedings in the cases for classification of contractual provisions found in standard forms of agreement provisions as abusive clauses.

JEL: K12; K20; K23 


\section{Introduction}

The Polish Act on Competition and Consumer Protection was adopted in $2007^{1}$ and came into force on 21 April 2007. It regulates both competition and consumer protection issues. In 2014, the Polish legislature decided to adopt the Amendment Act of $2014^{2}$ designed to strengthen competition protection ${ }^{3}$. The changes covered by this Amendment Act relate to, in particular, the enforcement of the prohibition of anti-competitive practices and merger control proceedings (see the critical analysis of the changes introduced by the Amendment Act of 2014: Skoczny, 2015, p. 165-183; Piszcz, 2016).

Shortly after the Amendment Act of 2014 came into force on 31 March 2015, a pre-consultation meeting was organized, the purpose of which was to discuss the scope of the planned changes in the Competition Act in the field of consumer protection. The draft of the Amendment Act was sent for interministerial consultations and public consultation on 15 April 2015. As it was indicated in the explanatory notes accompanying the draft Amendment Act of 2015, competition and consumer protection issues are strongly linked. After competition protection was strengthened by the adoption of the Amendment Act of 2014, it was, therefore, also necessary to adopt changes in the field of consumer protection 4 .

Hence, the Act of 5 August 2015 amending the Act on Competition and Consumer Protection and certain other acts ${ }^{5}$ introduced several changes mainly connected to the consumer protection area. A substantial part of this Act concerns abstract control of standard forms of agreements concluded with consumers. It replaces the earlier "court proceedings model" with an "administrative proceedings model". Those are not, however, the only changes introduced by the Amendment Act of 2015. The remaining changes concern,

1 The Act of 16.02.2007 on the Competition and Consumers Protection (consolidated text: Journal of Laws 2015, item 184 as amended); available in English at http://www.UOKiK.gov. pl/competition_protection.php (23.07.2016). Hereinafter, Competition Act.

2 The Act of 10.06.2014 amending the Act on Competition and Consumers Protection and the Code of Civil Procedure (Journal of Laws 2014, item 945); unavailable in English. Hereinafter, the Amendment Act of 2014.

3 Explanatory notes accompanying the draft of Act amending the Act on Competition and Consumers Protection and the Code of Civil Procedure, p. 1; available at http://www.sejm.gov. pl/Sejm7.nsf/PrzebiegProc.xsp?nr=1703 (23.07.2016); unavailable in English.

4 Explanatory notes accompanying the draft of Act amending the Act on Competition and Consumer Protection and certain other acts, p. 1; available at http://www.sejm.gov.pl/Sejm7. nsf/PrzebiegProc.xsp?nr=3662 (23.07.2016); unavailable in English.

5 Journal of Laws 2015, item 1634; unavailable in English. Hereinafter, the Amendment Act of 2015. 
amongst others, the protection of consumers on the financial services market ${ }^{6}$, the powers of investigation of the President of the Office of Competition and Consumer Protection (in Polish: Prezes Urzędu Ochrony Konkurencji $i$ Konsumentów, hereinafter, UOKiK President) $)^{7}$, the communication of decisions in all cases within the jurisdiction of the UOKiK President, as well as information connected to the protection of consumer interests. The explanatory notes accompanying the draft of this Amendment Act reveal that the main purpose of its adoption was not only to strengthen the powers of the UOKiK President meant to prevent the violations of consumer interests, but also to answer the needs expressed by undertakings concerning, among others, an increase in legal certainty ${ }^{8}$.

Due to the extent of the issues covered by the Amendment Act of 2015, this review will focus only on those amendments that are strictly connected to changes introduced to abstract control of standard forms of agreements concluded with consumers. As a result, the paper will not cover other amendments as, in the author's opinion, they require a comprehensive analysis in a separate paper.

Before commencing the analysis of the Amendment Act of 2015 regarding changes in the area of abstract control of standard forms of agreements concluded with consumers, it should be noted that the introduction into domestic legal systems of rules that enable control of terms used in contracts concluded with consumers by sellers or suppliers is required by Council Directive 93/13/EEC of 5 April 1993 on unfair terms in consumer contracts ${ }^{9}$. According to Article 7 paragraph 2 and 3 of this Directive, each member state shall include provisions which authorize any persons or organizations, having a legitimate interest under national law in protecting consumers, to take action for a decision as to whether contractual terms drawn up for general use are unfair. Such control may be made before the courts or before competent

6 The explanatory notes indicate also the problem which is particularly present on the financial services market - selling of a product that does not match the purchaser's needs (Explanatory notes accompanying the draft of Act amending the Act on Competition and Consumer Protection and certain other acts, p. 2-5). In order to strengthen the position of consumers on the financial services market, a new consumer interests' restricting practice has been introduced, i.e. proposing to consumers financial services which do not match the needs of those consumers or proposing the purchase of services in a manner unsuitable to the nature of those services.

7 The Amendment Act of 2015 grants to the UOKiK President two new investigative powers: the power to request information without prior initiation of proceedings and the power to take steps to purchase a product for the purpose of collecting information that may constitute evidence concerning practices infringing collective consumer interests (a mystery shopper).

${ }^{8}$ Explanatory notes accompanying the draft of Act amending the Act on Competition and Consumer Protection and certain other acts, p. 1.

9 OJ L 95, 21.04.1993, p. 29-34 (hereinafter, the Directive). 
administrative bodies. The decision as to whether control of such contractual provisions should be made in proceedings held before a court or before competent administrative bodies has been left to member states.

Taking into consideration the fact that Polish legal rules on abstract control of standard forms of agreements concluded with consumers constitute the measure required by aforementioned EU law, the question arises as to whether the new Polish model may be deemed as an appropriate and effective means of preventing the continued use of unfair terms within the meaning of the Directive. In order to find an answer to the above question, the paper analyses the new model of abstract control of standard forms of agreements concluded with consumers and compares it with the previous legal rules.

\section{New model of abstract control of standard forms of agreements concluded with consumers}

\section{Proceedings in cases for the classification of contractual provisions found in standard forms of agreements as abusive clauses}

The Polish model of control of standard forms of agreements concluded with consumers provides for two different types of proceedings: "individual control" and "abstract control". The former is undertaken via court proceedings where the court controls the terms of a standard form of an agreement concluded between a consumer and an undertaking, both being party to given proceedings. In other words, in this type of proceedings, the court controls the terms of a standard form of agreement on the basis of an individual contract that had already been concluded by the procedural parties. By contrast, abstract control is undertaken in specific proceedings where the terms of a standard form of an agreement are controlled regardless of the legal relationship between the parties and the agreement concluded by them. While the Amendment Act of 2015 has completely changed the model of abstract control proceedings, individual control proceedings have not been modified. Abstract control was introduced into the Polish legal system by the Act of 2 March 2000 on the protection of certain consumer rights and liability for damage caused by a hazardous product ${ }^{10}$, which came into force on 1 July 2000.

Before the Amendment Act of 2015 came into force, abstract control of standard forms of agreements concluded with consumers was undertaken

10 Journal of Laws 2000, Number 22, item 271; unavailable in English. 
through court proceedings. They were initiated, in the first instance, before the Regional Court of Warsaw - the Court of Competition and Consumer Protection (in Polish: Sąd Ochrony Konkurencji i Konsumentów, hereinafter, SOKiK $)^{11}$. The standing to bring an action before the court in order to initiate abstract control of standard forms of agreements was granted to a wide circle of entities: anyone who according the defendant's offer could conclude a contract containing a provision which was being controlled, nongovernmental consumer organizations (national, as well as, since 15 December 2002, also foreign ${ }^{12}$ ), district (municipal) consumer ombudsman, and the UOKiK President.

The Amendment Act of 2015 changes abstract control proceedings completely switching it from the court proceedings model into the administrative proceeding model conducted by the UOKiK President. As a result, a new type of proceedings were created to be conducted before the UOKiK President - proceedings in cases for the classification of contractual provisions found in standard forms of agreements as abusive clauses ${ }^{13}$. Hence, since 17 April 2016, Article 47(1) of the Competition Act contains four separate types of proceedings conducted by the UOKiK President on the basis of the Competition Act: preliminary proceedings, antitrust proceedings, proceedings in cases for the classification of contractual provisions found in standard forms of agreements as abusive clauses, and proceedings in the case of practices infringing collective consumer interests. The change of the model of abstract control of standard forms of contractual provisions does not mean that the role of SOKiK in this type of control has been eliminated-SOKiK is competent to hear appeals against decisions issued by the UOKiK President in this regard.

11 Hereinafter, SOKiK. Appeals from the SOKiK's judgments are heard by the Court of Appeals in Warsaw (in Polish: Sad Apelacyjny w Warszawie), whereas cassation appeals filed against rulings of the Court of Appeals in Warsaw are heard by the Supreme Court (in Polish: Sąd Najwyższy).

12 This applied only to a foreign consumer organization, which was entered on the list of organizations authorized in the European Union to initiate proceedings for the classification of clauses in standard forms of agreement as illegal, published in the Official Journal of the European Communities, provided that the purpose of its activity justified the requested control regarding the standard forms of agreements used in Poland, which threatened the interests of consumers in the country where this organization was registered. Such foreign consumer organizations received the right to initiate proceedings by the Act of 05.07 .2002 amending the Act on Competition and Consumers Protection and the Code of Civil Procedure and Act on Unfair Competition (Journal of Laws 2002, Number 129, item 1102); unavailable in English.

13 The Directive uses the term 'unfair term' whereas the Polish law uses the term 'abusive clause'. Due to the fact that this article concerns Polish legal rules on the new model of abstract control of standard forms of agreements concluded with consumers the author will use the term 'abusive clause'. 
Proceedings in cases for the classification of contractual provisions found in standard forms of agreements as abusive clauses are being initiated by the UOKiK President acting ex officio. The fact that the Amendment Act of 2015 does not give the right to initiate abstract control proceedings to any other entity constitutes a major change in comparison to the previous court proceedings model, where a lawsuit brought by an authorized entity initiated the proceedings. It should be noted that under the previous legal rules on abstract control proceedings, massive lawsuits in this kind of cases ${ }^{14}$ were brought mostly by consumer organisations ${ }^{15}$. As it was stated in the explanatory notes accompanying the draft of the Amendment Act of 2015, the proposed changes were meant to reduce actions of some quasi-consumer organisations that were pursuing cases in order to receive financial profits ${ }^{16}$. The current solution should inevitably decrease the number of proceedings in the cases for the classification of contractual provisions found in standard forms of agreements as abusive clauses. This is supported by the information that until 22 June 2016, the UOKiK President has not initiated any proceedings in cases for the classification of contractual provisions found in standard forms of agreements as abusive clauses ${ }^{17}$.

The resolution that institutes proceedings may be preceded by a written notification submitted to the UOKiK President of a suspected infringement of the prohibition of using abusive clauses in standard forms of agreements referred to in Article 23a of the Competition Act. According to Article 99a(1) of the Competition Act, the following entities are entitled to submit such written notifications: a consumer, consumer ombudsman, the Insurance Ombudsman (in Polish: Rzecznik Konsumentów), a consumer organisation or a foreign organisation. The latter must be registered on the list of organisations which have the power in EU Member States to file a request for proceedings to be instituted concerning the classification of clauses in standard agreements as abusive, published in the Official Journal of the European Communities, where the object of the activity of such organisation warrants the submission by such organisation of a notification concerning standard agreements used in

14 The number of cases regarding abstract control pending before SOKiK: in $2011-5976$, in 2012 - 13954, in 2013 - 41016, in $2014-3109$, in 2015 - 1968.

15 On 31.12.2015, there were 6227 abusive clauses entered into the register of provisions of standard forms of agreements classified as abusive clauses. In 3424 of those cases consumers organisations acted as plaintiffs - this means that almost $55 \%$ of those cases were initiated by consumer organisations. However, this statistics involves only those proceedings, which have ended with a judgment recognizing a controlled contractual provision as an abusive clause.

16 Explanatory notes accompanying the draft of Act amending the Act on Competition and Consumer Protection and certain other acts, p. 8.

17 Data on the basis of a response to a request for public information (motion no. BP/0143-569/16). 
the Republic of Poland which jeopardise collective consumer interests in the Member State where the organisation has its seat. The written notification of a suspected infringement of the prohibition referred to in Article 23a of the Competition Act is not binding on the UOKiK President. This means that in any case the UOKiK President remains independent to decide whether to initiate abstract control proceedings or not. Nevertheless, due to the nonbinding character of the written notification of a suspected infringement, even if the UOKiK President receives such notification from an entity not listed in the above legal rules, this will not deprive the UOKiK President of the right to initiate proceedings.

Another change introduced by the Amendment Act of 2015 is the limitation of the scope of entities who are party to the proceedings regarding abstract control of standard forms of agreements concluded with consumers. Under the previous legal rules (court proceedings model), the following entities were party to such proceedings: the plaintiff (the entity that brought the action before SOKiK in order to initiate abstract control proceedings) and the defendant (the undertaking that used a standard form of an agreement that included a contractual provision which was subject to the abstract control in the specific proceedings). Those entities had a wide scope of powers that could have been used in order to influence the judgement (for instance, the right to present evidences, the right to present their views, the right to appeal the decision etc.). In the proceedings for the classification of contractual provisions found in standard forms of agreements as abusive clauses initiated on the basis of Poland's new legal rules (that is, those initiated as of 17 April 2016), the status of a procedural party is granted only to the investigated entity, that is, the undertaking against which the proceedings have been initiated ${ }^{18}$. Due to the fact that such proceedings are initiated against the entity that included a contractual provision which is subject to abstract control in proceedings conducted by the UOKiK President, the new abstract control model has only one party to the proceeding - the undertaking that uses or used to use the term subject to the control.

Importantly, the entity that submits to the UOKiK President a written notification of a suspected infringement of the prohibition of using abusive clauses in standard forms of agreements referred to in Article 23a of Competition Act, does not have the status of a procedural party. The entity authorised under the Article 99a(1) of the Competition Act to submit such a notification may only apply to the UOKiK President to become an interested party, who is not, however, a procedural party and whose rights in such proceeding are limited to two powers only: the power to file documentation

18 Article 99b(1) of the Competition Act. 
and explanations as to the facts of the case, and the power to review the case files $^{19}$. An interested party does not have the right to appeal the decision ${ }^{20}$, which means that the UOKiK President's decision can be appealed only by the investigated entity. It should be emphasised that when proceedings are initiated as a result of information and evidences indicated in a notification of a suspected infringement of the prohibition referred to in Article 23a of Competition Act from an entity not listed in Article 99a(1) of the Competition Act, such entity cannot become an interested party (see Jurkowska-Gomułka, 2016, p. 113). The design of Poland's new legal rules regarding the scope of the entities that act in proceedings regarding abstract control of standard forms of agreements concluded with consumers, as well as rights given to such entities, leads to a serious limitation of the role of consumer organisations in abstract control proceeding (on the status and the role of consumer organisations in abstract control proceedings see more: Korycińska-Rządca, 2016b, p. 18-28).

Proceedings in cases for the classification of contractual provisions found in standard forms of agreements as abusive clauses shall last no longer than four months and, in particularly complex cases, five months from the date when it was initiated ${ }^{21}$. However, the indicated length of the proceedings is of an instructive nature only (Namysłowska, 2016b, p. 127). Under the previous legal rules, there was no deadline for the court proceeding before SOKiK to be closed.

\section{Decisions in cases for the classification of contractual provisions found in standard forms of agreements as abusive clauses}

Proceedings in cases for the classification of contractual provisions found in standard forms of agreements as abusive clauses can end with the following decisions:

1) decision classifying a clause found in a standard form of an agreement as abusive and prohibiting the use of that clause ${ }^{22}$ or by a commitment decision $^{23}$;

2) decision on the discontinuation of the proceedings ${ }^{24}$.

19 Article 99c(5)-(6) of the Competition Act.

20 Article 99c(7) of the Competition Act.

21 Article 99e of the Competition Act.

22 Article 23b(1) of the Competition Act.

23 Article 23c(1) of the Competition Act.

24 Article 83 of the Competition Act in connection to Article 105 of the Act of 14.06 .1960 - Code of Administrative Procedure (consolidated text: Journal of Laws 2016, item 23 as amended). 
A decision classifying a clause found in a standard form of an agreement as abusive as well as prohibiting the use of that clause is issued if the UOKiK President finds the prohibition specified in Article 23a of the Competition Act to have been infringed. According to rules on the limitation period, referred to in Article 99f of the Competition Act, the fact that the contested contractual provision has ceased to be applied does not exclude the issuance of this type of decision, provided the proceedings were initiated before the period stipulated in this legal rule has passed ${ }^{25}$. In a decision classifying a clause found in a standard form of an agreement as abusive, the UOKiK President may also specify measures for remedying the ongoing effects of the infringement of the prohibition referred to in Article $23 \mathrm{a}^{26}$. Such measures may be imposed only if they are proportionate to the severity and nature of the infringement as well as necessary to remedy its consequences ${ }^{27}$. Article $23 \mathrm{~b}(2)$ of the Competition Act indicates what exemplary, informative measures may be imposed in this context: to inform consumers who are party to individual contracts based on the applicable standard form of an agreement that clauses contained therein have been recognized as abusive, or to make a single, or recurring statement of the wording and in the form specified in the decision. The UOKiK President can also impose different measures not listed in this legal rule. In such decision, the UOKiK President may order that the decision shall be published in whole or in part, indicating clearly whether the decision is legally binding, in the form specified therein, at the undertaking's expense ${ }^{28}$. The publication of a decision classifying a clause found in a standard form of an agreement as abusive, may contribute to enhancing the effectiveness of the abstract control of standard forms of an agreement as it helps communicate more easily the abusive nature of a given contractual provision to consumers, and encourage them to undertake steps in order to defend their rights. The Amendment Act of 2015 authorises the UOKiK President to rule that the decision is immediately enforceable in whole or in part where an important consumer interest so requires ${ }^{29}$.

The possibility of the issuance of a commitment decision has been indicated in Article 23c(1) of the Competition Act. However, the wording of this legal rule leads to the conclusion that a commitment decision does not constitute a separate type of decision but rather is a part of a decision classifying a clause in a standard form of an agreement as abusive, issued under the Article 23b(1) of the Competition Act (Namysłowska, 2016a, p. 33). This

\footnotetext{
25 About the limitation period see the remarks in II.3. of this article.

26 Article 23b(2) of the Competition Act.

27 Article 23b(4) of the Competition Act.

28 Article 23b(3) of the Competition Act.

29 Article 99d of the Competition Act.
} 
differentiates a commitment decision issued in abstract control proceedings from commitments decisions that may be issued in other proceedings conducted by the UOKiK President, that is, in antitrust proceedings (Article 12 of the Competition Act) and in proceedings concerning practices infringing collective consumer interests (Article 28 of the Competition Act). The introduction of the possibility to issue a commitment decision has been seen by the authors of the draft of Amendment Act of 2015 as beneficial from both consumers' (it should eliminate the abusive clauses quicker) and undertakings' (a fine will not be imposed on the undertaking and the undertaking will have an impact on the imposed commitments) point of view ${ }^{30}$. In order to issue a commitment decision the following premises have to be fulfilled: 1) a decision classifying a clause in a standard form of an agreement as abusive shall be issued; 2) the undertaking shall make a commitment to take or cease certain actions in order to stop the infringement of the prohibition referred to in Article 23a of the Competition Act; 3 ) the commitment shall be made prior to the issuance of the decision referred to in Article 23b(1) of the Competition Act. The fulfilment of all of those premises is a condition sine qua non of the issuance of the commitment decision. However, even if all of those premises are fulfilled, the UOKiK President is not obliged to issue such a decision as the issuance of a commitment decision depends on the UOKiK President's discretion. The UOKiK President may specify the time limit for the fulfilment of the commitment and may impose on the undertaking an obligation to provide, within a specified time frame, information regarding the extent of the fulfilment of the commitments ${ }^{31}$. A commitment decision may be revoked in that part which concerns the commitments if: 1) the decision was issued on the basis of false, incomplete or misleading information or documents; 2) the undertaking has not complied with the commitments or obligations. If the UOKiK President revokes the commitment decision on the abovementioned legal basis, he may impose a fine on the undertaking. A commitment decision may also be revoked, this time upon the undertaking's consent, with regard to that part of the decision which concerns the commitments, if circumstances, having a significant impact on the issuance of the decision, have changed ${ }^{32}$. However, in this situation, the UOKiK President is not entitled to impose a fine on the undertaking (Namysłowska, 2016a, p. 40-41).

The last type of decision that the UOKiK President can issue in abstract control proceedings is a decision on the discontinuation of the proceedings. This type of decision is issued when the proceedings do not provide evidences

${ }^{30}$ Explanatory notes accompanying the draft of Act amending the Act on Competition and Consumers Protection and the Code of Civil Procedure, p. 20.

31 Article 23c(2)-(3) of the Competition Act.

32 Article 23c(7) of the Competition Act. 
that the prohibition referred to in Article 23a of the Competition Act has been infringed or when the UOKiK President initiated proceedings despite the fact that the limitation period stipulated in Article 99f of the Competition Act had already passed ${ }^{33}$.

By way of the Amendment Act of 2015, the Polish legislature has also eliminated doubts which had existed with relation to the earlier control model concerning the binding force of final judgements declaring a specific contractual provision to be an abusive clause. According to Article $479^{43}$ of the Code of Civil Procedure, a final judgement has an effect from the moment when the contractual provision classified as abusive has been entered into the register of provisions of standard forms of agreements recognized as abusive clauses. Two interpretations were possible on the basis of this legal rule: 1) the ban imposed on using the abusive clause applied only to the undertaking that was the party to the abstract control proceedings ${ }^{34}$ or 2) the contractual provision classified as an abusive clause in abstract control proceedings and entered into the register cannot be used by any undertaking, that is, this prohibition applies also to undertakings that were not party to the given proceedings ${ }^{35}$. In recent jurisprudence, the first interpretation prevails ${ }^{36}$. However, doubts as to the scope of the binding force have not been dispelled (on the binding force of SOKiK judgements recognizing contractual provisions as abusive see more: Korycińska-Rządca, 2016a, p. 175-190). The Amendment Act of 2015 introduced Article 23d into the Competition Act whereby a legally binding decision recognizing a clause in a standard form of agreements as abusive is effective with respect to the undertaking determined to be using the abusive clause and with respect to all consumers who have concluded an agreement with that undertaking on the basis of the standard form of an agreement specified in that decision. This legal rule applies to a decision issued on the basis of Article 23b(1) of the Competition Act as well as on the basis of Article 23c(1) of the Competition Act (commitment decision).

The new legal rules on the scope of the binding force of a decision classifying a clause in a standard form of agreements as abusive shall be assessed positively for the following reasons: 1) it clearly indicates the scope of the binding force, dispelling any doubts existing on the basis of the former legal rules, 2) it protects

33 About the limitation period see in II.4. of this paper.

34 See e.g.: Polish Supreme Court judgements of 12.04.2011, III SK 44/10, of 30.05.2014, III CSK 204/13; Court of Appeals in Kraków of 09.06.2015, I ACa 404/15, Court of Appeals in Warsaw of 04.11.2014, VI ACa 74/14.

35 Polish Supreme Court resolution of 13.07.2006, III SZP 3/06.

36 See: Polish Supreme Court resolution of 20.11.2015, III CZP 17/15; available in Polish at http://www.sn.pl/ (30.07.2016) as well as Polish Supreme Court judgements of 12.04.2011, III SK 44/10, of 30.05.2014, III CSK 204/13. Differently: Polish Supreme Court decision of 14.02.2012, III SK 32/11, Court of Appeals in Warsaw of 29.11.2012, VI ACa 821/12. 
the right to defence of undertakings that were not a party to the proceedings regarding abstract control of provisions found in the standard form of an agreement that were ultimately classified as abusive, and 3) it protects all consumers that are (or could be) parties to a contract using an abusive clause. Moreover, the new rules are in compliance with recent judgements regarding the interpretation of Article $479^{43}$ of the Code of Civil Procedure ${ }^{37}$.

\section{Limitation period}

Under Article $479^{39}$ of the Code of Civil Procedure ${ }^{38}$, which has been repealed by the Amendment Act of 2015, an action to recognize the provisions of standard forms of agreements as abusive clause could not be brought if the defendant discontinued the use of this provision not later than six months earlier. This relatively short limitation period has been extended by the Amendment Act of 2015. As a result, from 17 April 2016, proceedings for the classification of contractual provisions found in standard forms of agreements as abusive clauses shall not be initiated if three years have passed since the end of the year when the provision had ceased to be applied ${ }^{39}$. It was indicated in the explanatory notes accompanying the draft of the Amendment Act of 2015 that the 3-years period was an optimal period of time allowing for the effective prosecution of undertakings using abusive clauses, including those provisions that ceased to be applied. Simultaneously however, it did not overextend the period of the threat of a fine ${ }^{40}$.

Article 99f of the Competition Act excludes only the possibility to initiate abstract control proceedings after the limitation period has passed. It does not, however, limit the UOKiK President's power to issue a final decision in this kind of proceedings, provided they had been initiated before the 3 -years period referred to in this legal rule had passed (see: Namysłowska, 2016c, p. 128). Hence, if proceedings for the classification of contractual provisions found in standard forms of agreements as abusive clauses are initiated despite the fact that the limitation period indicated in Article 99f of the Competition Act had passed, the UOKiK President is obliged (acting ex officio) to discontinue the proceedings due to the fact that the proceedings are groundless (Miąsik, 2014, p. 1208).

${ }^{37}$ See the judgements indicated above.

38 Act of 17.11.1964 - the Code of Civil Procedure (consolidated text: Journal of Laws 2014, item 101 as amended).

39 Article 99f of the Competition Act.

40 Explanatory notes accompanying the draft of Act amending the Act on Competition and Consumers Protection and the Code of Civil Procedure, p. 21. 


\section{Fines}

The Amendment Act of 2015 extends the list of infringements for which the UOKiK President may impose a maximum fine of $10 \%$ of the turnover generated in the financial year preceding the year in which the fine is imposed. Since 17 April 2016, alongside the infringement of the prohibition of competition-restricting practices, performing a concentration without obtaining consent from the UOKiK President, and an infringement of the prohibition of practices infringing collective consumer interests, the aforementioned fine may be imposed for an infringement of the prohibition provided for in Article 23a of the Competition Act. This change is connected to the change of the model of abstract control proceedings of standard forms of agreements that are controlled in the new proceedings conducted by the UOKiK President. As indicated in the explanatory notes accompanying the draft of the Amendment Act of 2015, the introduction of fines for the infringement of the prohibition imposed on the use of abusive clauses in consumer contracts was necessary to ensure the effectiveness of this prohibition ${ }^{41}$.

The introduction of a fine for the infringement of the prohibition indicated in Article 23a of the Competition Act shall be assessed positively. However, the manner of calculating the fine may raise objections. The authors of the draft of the Amendment Act of 2015 have not explained the reasons for their decision to introduce financial penalties that might result in very high fines. Still, Article 106(1) of the Competition Act only stipulates the maximum amount of the fine it does not prevent the UOKiK President from imposing a fine of a lower level. That is so especially since the determination of the amount of the fine for an infringement of Article 23a of the Competition Act shall be made in accordance with the rules indicated in Article 111 of the Competition Act.

\section{Role of the register of contractual provisions found in standard forms of agreements classified as abusive clauses}

While implementing the Directive, the Polish legislature decided that in order to eliminate abusive clauses from contracts concluded with consumers, a register of contractual provisions found in standard forms of agreements classified as abusive clauses shall be created ${ }^{42}$. According to Article $479^{45} \S 1$ and $\S 2$ of

41 Explanatory notes accompanying the draft of Act amending the Act on Competition and Consumers Protection and the Code of Civil Procedure, p. 23.

42 Explanatory notes accompanying the government draft of Act on the contracts concluded of contracts concluded outside the business premises or at a distance and amending the Acts: the Civil Code, the Code of Civil Procedure and the Code of Petty Offenses, that was submitted 
the Code of Civil Procedure, a copy of a final court judgement upholding the claim, that is, a ruling classifying a given contractual provision as abusive, is sent to the UOKiK President in order for it to be entered into the register of the provisions of standard forms of agreements classified as abusive clauses ${ }^{43}$. The idea to introduce a register into the Polish legal order was taken from France ${ }^{44}$.

The register of provisions found in standard forms of agreements classified as abusive clauses was subject to criticism, especially due to the fact that the register was overextended ${ }^{45}$ and the abusive clauses were entered chronologically. Moreover, the data published in the register did not make the verification possible of the reasons for a judgment classifying a given contractual provision as an abusive clause (see: Marecki and Witkowski, 2013, p. 18D-19D; Wyżykowski, 2013, p. 36). Voices emerged in literature that the reasons for judgments should be published ${ }^{46}$, but there was no legal basis for that. The verification of the register by entrepreneurs was thus complicated.

The Amendment Act of 2015 introduced a new manner of communication of provisions found in standard forms of agreements classified as abusive clauses by the UOKiK President. Since 17 April 2016, each decision issued by the UOKiK President shall be published on the website of the Office of Competition and Consumer Protection (in Polish: Urzad Ochrony Konkurencji i Konsumentów $)^{47}$, albeit without business secrets or other information protected under separate legal rules ${ }^{48}$. The publication of the entire decision enables interested parties to check why the given provision was classified as abusive. The Polish legislature has decided that there was no justification to uphold the register of the provisions found in standard forms of agreements classified as abusive clauses. At the same time, however, the legislature decided that the register, in the same form, will exist for the next 10 years from the date when the Amendment Act of 2015 comes into force (in other words, until 17 April

to the Sejm on 26.02.1999, p. 15; available at http://orka.sejm.gov.pl/ (23.07.2016); unavailable in English.

43 The register of provisions of standard forms of agreements recognized as abusive clauses is available at: https://uokik.gov.pl/rejestr_klauzul_niedozwolonych2.php.

44 Explanatory notes accompanying the government draft of the Act on the contracts concluded outside business premises or at a distance and amending the Acts: the Civil Code, the Code of Civil Procedure and the Code of Petty Offenses, that was submitted to the Sejm on 26.02.1999, p. 15; available at http://orka.sejm.gov.pl/ (23.07.2016); unavailable in English.

45 On 22.07.2016 there were 6513 abusive clauses entered into the register of provisions of standard forms of agreements recognized as abusive clauses.

$46 \mathrm{P}$. Marecki and S. Witkowski suggested that the reasons for the judgements should be published in an electronic data base available on the website of the Office of Competition and Consumer Protection (see: Marecki and Witkowski, 2013, p. 21D). Also: Korycińska-Rządca, 2016a, p. 175-190.

47 Hereinafter, the UOKiK Office.

48 Article $31 \mathrm{~b}$ of the Competition Act. 
2026). However, the provisions the legality of which will be questioned by the UOKiK President from now on shall not be entered therein. This basically means that from 17 April 2016 onwards, two manners of communication of the wording of abusive clauses coexist in Poland depending on the legal rules on the basis of which the legality of the given provision is questioned. First, those provisions which are recognized as abusive clauses in court proceedings conduced on the basis of the previous rules are entered into the register. Second, those provisions that will be recognized as abusive clauses by the UOKiK President in proceedings in cases for the classification of contractual provisions found in standard forms of agreements as abusive clauses will be published together with the entire decision on the website of the UOKiK Office (about the role of the register of provisions of standard forms of agreements recognized as abusive clauses after 17 April 2016 see more in: Korycińska-Rządca, 2016a, p. 175-190).

The aforementioned changes regarding the manner of communication of decisions issued in cases of abstract control of consumer contract terms should enable entrepreneurs to uncover the reasons for the decision to classify a given term as abusive. However, the change of the manner of communication of contractual provisions classified as abusive clauses introduced by the Amendment Act of 2015 means that as of 17 April 2016, Polish law no longer provides for a document that includes all of the contractual provisions classified as abusive clauses. The register will exist for the next 10 years, but it will not be expanded to include contractual provisions classified as abusive from now on by the UOKiK President. Therefore, the register will slowly become a historical document. Unfortunately, Polish legislature did not introduce another register that could replace the current one.

\section{Conclusions}

In the author's opinion, the new changes introduced into the Polish legal rules on abusive clauses in standard forms of consumer contracts are, as a rule, in compliance with the pattern of such control established by the Directive. Most of the adopted amendments have the potential to strengthen consumer protection. First of all, they should decrease the number of proceedings regarding abstract control of contractual terms in consumer contracts due to the fact that decisions whether abstract control of contractual terms in consumer contracts should be initiated or not will belong solely to the UOKiK President. Therefore, the phenomenon of massive abstract controls of terms of contracts concluded with consumers should end. This creates hope that the 
institution of abstract control of terms in contracts concluded with consumers will be used for the purpose for which it was initially created. Second, changes regarding the manner of communication of decisions in cases of abstract control of consumer contract terms should enable undertakings to uncover the reasons for the classification of a given contractual provision as abusive. However, the decision to dissolve the register of contractual provisions of standard forms of agreements classified as abusive clauses raises the question whether its elimination was necessary. It is likely that an extension of the current register, in order to include at least a short explanation of the reasons for a given decision, would be sufficient to counteract the criticism directed towards the initial model of the register.

Regarding the new Polish model of the abstract control of standard forms of agreements concluded with consumers under the Competition Act, most concerns are linked to the serious limitations of the role of consumer organizations. In the author's opinion, such a significant limitation of their role was not justified. The fact that consumer organizations exploited the previously applicable legal rules in order to gain financial profits was not an adequate reason to introduce such limitations. That is so especially, since the first step aimed at reducing the numbers of cases initiated by consumer organizations was taken thanks to a reduction in attorneys' fees in those proceedings, which took place in $2013^{49}$. This change has significantly decreased case numbers proving that this method might have been appropriate to regain the initial purpose of this proceeding. Moreover, in the author's opinion, a serious limitation of rights previously granted to consumer organizations leads to the conclusion that consumer organizations are not likely to engage in abstract control proceedings conducted by the UOKiK President.

\section{Literature}

Jurkowska-Gomułka, A. (2016). Art. 99a. In M. Namysłowska, A. Piszcz (eds), Ustawa $o$ zmianie ustawy o ochronie konkurencji $i$ konsumentów z 5.8.2015 $r$. Komentarz. Warszawa: Wydawnictwo C.H. Beck, 109-118.

Korycińska-Rządca, P. (2016a). Elektroniczny rejestr postanowień wzorców umowy uznanych za niedozwolone po 17.04.2016 r. In J. Bieluk, A. Marciniak (eds), Postępowanie i prawo cywilne $w$ dobie informatyzacji. Sopot: Currenda.

49 The Ordinance of the Minister of Justice of 23.01.2013 amending the ordinance on legal advisors' fees and the covering by the State Treasury of the costs of legal assistance provided by court-appointed counsel (Journal of Laws 2002, No. 163, item 1348) has reduced the fees of legal advisors in proceedings in cases for the classification of contractual provisions found in standard agreements as abusive clauses from 360 PLN to 60 PLN. 
Korycińska-Rządca, P. (2016b). Status prawny i rola organizacji konsumenckich w postępowaniu w sprawach o uznanie postanowień wzorca umowy za niedozwolone. internetowy Kwartalnik Antymonopolowy i Regulacyjny 3(5), 18-28. DOI: 10.7172/2299-5749. IKAR.3.5.2.

Marecki, P. and Witkowski, S. (2013). Rejestr postanowień wzorców umowy uznanych za niedozwolone - identyfikacja aktualnych problemów i propozycje zwiększenia efektywności rejestru. Radca Prawny 138, 16D-21D.

Miąsik, D. (2014). Art. 105. In T. Skoczny (ed.), Ustawa o ochronie konkurencji i konsumentów. Komentarz. Warszawa: Wydawnictwo C.H. Beck, 1205-1208.

Namysłowska, M. (2016a). Art. 23c. In M. Namysłowska, A. Piszcz (eds), Ustawa o zmianie ustawy o ochronie konkurencji i konsumentów z 5.8.2015 r. Komentarz. Warszawa: Wydawnictwo C.H. Beck, 30-41.

Namysłowska, M. (2016b). Art. 99e. In M. Namysłowska, A. Piszcz (eds), Ustawa o zmianie ustawy o ochronie konkurencji i konsumentów z 5.8.2015 r. Komentarz. Warszawa: Wydawnictwo C.H. Beck, 126-128.

Namysłowska, M. (2016c). Art. 99f. In M. Namysłowska, A. Piszcz (eds), Ustawa o zmianie ustawy o ochronie konkurencji i konsumentów z 5.8.2015 r. Komentarz. Warszawa: Wydawnictwo C.H. Beck, 128-130.

Piszcz, A. (2016). A Note on 2015 Developments in Polish Competition Law: Is It Really a Drive Towards the European Model? YARS 9(14).

Skoczny, T. (2015). 2014 Amendment of the Polish Competition and Consumers Protection Act 2007. YARS 8(11), 165-183.

Wyżykowski, B. (2013). Abstrakcyjna kontrola postanowień wzorców umów. Przeglad Prawa Handlowego 10, 30-40. 